УДК 352.9

O. Sorokivska,

Doctor of Economic Sciences, Professor of the Department of management and administration, Ternopil Ivan Puluj National Technical University, Ternopil

ORCID ID: 0000-0001-8549-2910

T. Kuzhda,

$\mathrm{PbD}$ in Economics, Associate Professor of the Department of management and administration, Ternopil Ivan Puluj National Technical University, Ternopil

ORCID ID: 0000-0002-5962-0795

I. Lutsykiv,

$\mathrm{PbD}$ in Economics, Associate Professor of the Department of management and administration, Ternopil Ivan Puluj National Technical University, Ternopil

ORCID ID: 0000-0003-1307-3391

DOI: $10.32702 / 2306-6814.2021 .8 .88$

\title{
METHODOLOGY FOR EVALUATION ADMINISTRATIVE SERVICE CENTERS PERFORMANCE AND THEIR EMPLOYEES IN UKRAINE (BY USING DATA OF TERNOPIL REGION)
}

\author{
О. А. Сороківська, \\ А. е. н., професор кафедри менеджменту та адміністрування, \\ Тернопільський національний технічний університет імені І. Пулюя, м. Тернопіль \\ T. I. Кужда, \\ к. е. н., доцент кафедри менеджменту та адміністрування, \\ Тернопільський національний технічний університет імені I. Пулюя, м. Тернопіль \\ I. В. Ауциків, \\ к. е. н., доцент кафедри менеджменту та адміністрування, \\ Тернопільський національний технічний університет імені I. Пулюя, м. Тернопіль
}

МЕТОАОАОГІЯ ОЦІНЮВАННЯ ЕФЕКТИВНОСТІ ЦЕНТРІВ НАААННЯ ААМІНІСТРАТИВНИХ ПОС УГ ТА ЇХ ПРАЦІВНИКІВ В УКРАЇНІ (НА ПРИК АААІ ТЕРНОПІ ЬСЬКОЇ ОБ ААСТІ)

The purpose of this article is to develop and present the applied aspects of the evaluation methodology of the Administrative Service Centres performance and their employees and reveal some positive trends and some problematic moments of centres work. The main feature of proposed evaluation methodology is to study the Administrative Service Centre's activity for compliance with the requirements of the Law of Ukraine "On Administrative Services", regulatory documents, best practices and concept of an integrated office for provision of administrative services. The methodology describes the results of an online survey conducted by the authors on the impact of the implemented practical measures on Administrative Service Centers' efficiency in various aspects.

The actual state of quality/quantity of public service provision in Ternopil region have been examined and the results of peer-review and recommendations were sent to the officials of each cities and united territorial communities to get acquainted with the information, make rational managerial decisions and implement appropriate measures. The key criteria covering the most important areas of the Administrative Service Centre's activity and staff involved in administrative service delivery have been pointed out and evaluated in the study.

The article presents the practical significance of the proposed methodology for community development and highlights the practical benefits of the methodology for participants of providing, 
regulating and receiving administrative services including the Administrative Service Centres Management, Administrative Service Centre employees, experts, local governments, and service users.

Some positive trends and problematic moments in the administrative services provision have been revealed and some recommendations for improving the Administrative Service Centre work have been developed. The evaluation results will serve to monitor and systematize all key aspects of Administrative Service Centres work at the regional level and analyze growth rates in Centre' performance over time.

Метою статті є розроблення та представлення практичних аспектів методології оцінювання діяльності Центрів надання адміністративних послуг та їх працівників, а також з'ясування позитивних аспектів та проблематичних ситуацій у їхній діяльності. Особливістю запропонованої методології оцінювання діяльності ЦНАП є фіксування їхнього стану на відповідність вимогам Закону України "Про адміністративні послуги", нормативним документам і найкращим практикам та концепції інтегрованого офісуз надання адміністративних послуг. Представлена устатті методологія описує результати онлайн-опитування проведеного авторами про вплив впроваджених практичних заходів на діяльність Центрів надання адміністративних послуг у різних аспектах.

Досліджено реальний стан обсягу та якості надання адміністративних послугу Тернопільській області, а результати експертного оцінювання та відповідні рекомендації було надіслано керівництву кожного із досліджуваних міст та об'єднаних територіальних громад для ознайомлення, ухвалення необхідних управлінських рішень і впровадження відповідних заходів. У статті виокремлено та оцінено ключові критерії, які охоплюють найважливіші сфери діяльності Центру надання адміністративних послуг та персоналу, залученого до надання адміністративних послуг.

У статті представлено практичне значення запропонованої методології для розвитку громади та висвітлено практичні переваги методології для усіх учасників процесів надання, регулювання та отримання адміністративних послуг, включаючи керівництва та працівників Центрів надання адміністративних послуг, експертів, органів місцевого самоврядування та користувачів публічних послуг.

Наведено позитивні тенденції та проблемні питання діяльності, а також підготовлено адресні рекомендації щодо поліпшення роботи ЦНАП для кожного з досліджуваних міст і ОТГ. Результати проведеного оцінювання дозволили узагальнити та систематизувати ключові аспекти діяльності ЦНАПів на рівні регіону, розробити ряд рекомендацій і практичних заходів для удосконалення їх подальшого розвитку.

Key words: Administrative Service Centres, administrative service quality, service delivery, service refusals, and evaluation results.

Ключові слова: Центр надання адміністратиВних послуг, якість адміністратиВних послуг, процес надання послуг, ВідмоВа у наданні послуги, результати експертного оцінюВання.

\section{FORMULATION OF THE PROBLEM}

Ukraine has set out to decentralize and reform its administrative system. Therefore, one of the critical priorities of decentralization reform aims to create, develop, and improve administrative services and form an optimal Administrative Service Centres network. Also, the extension of Administrative Service Centres network facilitates the transfer of more authority to local governments to provide a broader range of public services, prepare suitable premises and form an appropriate service delivery infrastructure, in particular in the newly formed United Territorial Communities, thereby bringing administrative services closer to customer' needs. The Ministry of Economic Development and Trade and the Ministry of Regional Development, Building and Housing and Communal Services of Ukraine informing the state policy for Administrative Services Centres development is crucial in this process.

It should be noted that local governments are the most responsible for creating appropriate Administrative Services Centres and ensuring an effective decentralization process. The positive result of decentralization and citizens' satisfaction with public services quality depends on the right vision and practical cooperation between local self-government authorities and community. Sufficient work of the Administrative Service Centres should be based on standard approaches and specific criteria, such as: providing the top list of public services, accessibility and quality of public services, approved documents, trained staff, bringing administrative services closer to customer' needs through the opening territorial units and remote jobs. 
Table 1. Contest evaluation form sample "The best Administrative Services Centre"

\begin{tabular}{|c|c|c|}
\hline № & Criteria (indicator) & $\begin{array}{l}\text { Score } \\
\text { range }\end{array}$ \\
\hline 1 & $\begin{array}{l}\text { Compliance of the Administrative Service Centre' premises with } \\
\text { established standards }\end{array}$ & $1-5$ \\
\hline 2 & The actual number of administrators in the Administrative Service Centre & $1-5$ \\
\hline 3 & Number of administrative services provided per administrator per year & $1-5$ \\
\hline 4 & Availability of infrastructure for disabled people (ramp, call button, toilet, etc.) & $1-5$ \\
\hline 5 & $\begin{array}{l}\text { Technologically-advanced administrator' workplaces (computer, } \\
\text { photocopier, printer, etc.) }\end{array}$ & $1-5$ \\
\hline 6 & $\begin{array}{l}\text { Number of administrative service types provided by the Administrative } \\
\text { Service Centre and regulated by relevant legislation }\end{array}$ & $1-5$ \\
\hline 7 & $\begin{array}{l}\text { Free public access to bylaws, regulations, work schedules, information } \\
\text { cards for receiving administrative services and information stands }\end{array}$ & $1-5$ \\
\hline 8 & $\begin{array}{l}\text { Number of requests to the Administrative Service Centre / administrative } \\
\text { services provided }\end{array}$ & $1-5$ \\
\hline 9 & $\begin{array}{l}\text { The content of the Administrative Service Centre web-site / webpage } \\
\text { covering full information about its activities }\end{array}$ & $1-5$ \\
\hline 10 & $\begin{array}{l}\text { Provision of related services, in particular, making a payment for this } \\
\text { services (cash, non-cash, payment terminal) }\end{array}$ & $1-5$ \\
\hline 11 & $\begin{array}{l}\text { Feedback from the public, business entities and representatives of the } \\
\text { administrative service providers on the work of the Administrative } \\
\text { Service Centre registered in the established order during the previous } \\
\text { calendar year before the date of the competition (complaints and } \\
\text { suggestion box, positive feedback) }\end{array}$ & $1-5$ \\
\hline 12 & $\begin{array}{l}\text { The use of innovations in the Administrative Service Centre ensuring } \\
\text { effective work }\end{array}$ & $1-5$ \\
\hline 13 & $\begin{array}{l}\text { Has the Administrative Service Centre received assistance from local or } \\
\text { international technical assistance programs for the modernization or } \\
\text { creation of the Administrative Service Centre? If yes, in which ones? (EU } \\
\text { / UNDP, U-LEAD with Europe, GIZ, DOBRE, Transparent Office) }\end{array}$ & $1-5$ \\
\hline 14 & $\begin{array}{l}\text { Has the Administrative Service Centre previously participated in } \\
\text { competitions? If yes, in which ones and what exact place did Centre win? }\end{array}$ & $1-5$ \\
\hline \multicolumn{2}{|r|}{ Total Score (maximum) } & 70 \\
\hline
\end{tabular}

important economic and social aspects of combining local government units and the empirical research results concerning respondents' opinions both on positive and negative aspects of the merger of the Commune and the City $[3 ; 4 ; 7]$. The others have explored the spatial range of local governments and how geographical distance may affect governance and public service delivery [6], the market-based mechanism in public service delivery in local government in Poland [11], a digital transformation of public service delivery in Central and Eastern Europe [1; 2; 9].

As for Ukrainian scholars, some of them have developed the methodological framework for ensuring the provision of administrative services quality including the evaluation with the main steps: forming the requirements to the quality of administrative services provision; defining criteria for assessing the quality of service provision; selecting assessing tools for the quality of services and service providers' activity [8]; the others have offered a methodology for monitoring the Administrative Service Centers work that is mainly focused on criteria analysis of the Administrative service centres work [10] Some of the Ukrainian scholars have systematized their research results in the following areas: the general issues of reforming the administrative services; topical

Today, there are plenty of Administrative Services Centres in the Ternopil region in cities of oblast and rayon significance and newly established united territorial communities. Although many local governments have already passed a stage for establishing the Administrative Services Centres, the need for improvement many of them remain very urgent.

To examine the quality of administrative services and Administrative Services Centres activity, it is necessary to evaluate them periodically. It is essential for the evaluation to be systematic, based on a proven methodology, covered several evaluation tools and involved all stakeholders: community activists, NGOs, local, district and regional authorities, and independent experts. The practical evaluation will provide more objective information on the quality of public service provision. This evaluation is vital for prompt decision-making to realistically improve, and bring public services quality to match customer needs.

\section{LITERATURE REVIEW}

In different countries, the methodological approaches for assessing local government performanc concern local government's key features (how they contribute to democracy, public participation and improved service delivery), the legal framework and supervisory arrangements, and finances including local government expenditure and revenue sources.

When it comes to evaluating local governments activities in Poland, it should be noted that various scholars have devoted their articles to different aspects of such evaluation. Some of them have presented the most issues of establishing the Administrative Service Centers; public monitoring of the Administrative Service Centers; sociological surveying of the quality of administrative services; developing the ways for improving administrative services in Ukraine [12].

It should be singled out the methodology proposed by a team of Ukrainian scientists to evaluate service quality and administrative service centres activity involving several consistent and interrelated steps: defining requirements for the quality of administrative services; forming criteria for assessing the quality of services and standards for its provision; creating tools to evaluate the quality of service quality and Administrative Service Centers activity; developing assessment and recording methods; planning and evaluation; analyzing and reporting on evaluation results [5] and others).

Summarizing the study of scientific works, we have concluded that the evaluation methodology for assessing the Administrative Service Centres performance should consider specific features of the service centres and the information on how long they have been functioning. Therefore, we believe that the evaluation methodology should be refined and complemented due to changes in the internal and external environment.

\section{PURPOSE}

The purpose of the article is to to present the applied aspects of the Administrative Service Centres performance and their employees' evaluation methodology and reveal some positive trends and some challenging moments of centres work. 


\section{RESULTS \& DISCUSSION}

Administrative reform in Ukraine today sets out new requirements for evaluating the Administrative Services Centres activity in the United Territorial Communities, at the level of cities of oblast and rayon importance and district state administrations. The article explores the Administrative Services Centres of cities of oblast importance (Berezhany, Chortkiv and Ternopil); Administrative Services Centres of the united territorial communities (in Shumsk, Pidvolochysk, Skalat, Velyki Hai and Velyki Dederkaly); the Administrative Services Centres of district state administrations of cities of rayon importance (Berezhany, Borshchiv, Buchach, Zalishchyky, Zbarazh, Zboriv, Kozova, Kremenets, Lanivtsi, Terebovlya and Chortkiv).

The article aims to evaluate the Administrative Services Centres activity by the expert evaluation methods and examine the actual state of quality/quantity of public service provision. Peer-review and related recommendations were sent to the of ficials of each city and united territorial communities to get acquainted with the information, make rational managerial decisions, and implement appropriate measures.

The purpose of evaluating the Administrative Service Centres is to study its activity for compliance with the requirements of the Law of Ukraine "On Administrative Services", regulatory documents and best practices and concept of an integrated office for the provision of administrative services. It should be noted that an expert evaluation of the Administrative Service Centres activity in cities and the United Territorial Communities in Ternopil Oblast using a questionnaire developed by experts of the Ternopil regional state administration was conducted in 2019. The peerreview period covered April - August 2019. The questionnaire contained a range of evaluation criteria based on legislative, regulatory requirements and best practices of the Administrative Service Centres activity and an estimate (score) for each measures depending on its importance. These criteria covered the most critical areas of the Administrative Service Centres activity. The total questionnaire contained 14 measures, where 5 points were the maximum score of each standard. A sample evaluation form is given in table 1.

A questionnaire was also developed to identify the best Administrative Service Centre administrator during the assessment. This questionnaire covered six criteria, where 5 points are the maximum score for each measure. A sample evaluation form is given in table 2.

The experts have studied each Administrative Service Centres' information and documentation from open sources (primarily web resources). Local governments provided additional information at the expert requests.

The experts personally have examined the working conditions in the Administrative Service Centres, inspected premises (in terms of convenience for visitors, particularly for individuals with special needs), communicated with representatives of the
Table 2. Contest evaluation form sample "The best Administrative Service Centre' administrator"

\begin{tabular}{|l|l|l|}
\hline № & \multicolumn{1}{|c|}{ Criteria (indicator) } & \multicolumn{1}{|c|}{$\begin{array}{l}\text { Score } \\
\text { range }\end{array}$} \\
\hline 1 & $\begin{array}{l}\text { Administrator's working period in the Administrative Service } \\
\text { Centre on the day of the competition announcement }\end{array}$ & $1-5$ \\
\hline 2 & $\begin{array}{l}\text { Number of administrative services provided by the given } \\
\text { administrator for the previous year before the competition date }\end{array}$ & $1-5$ \\
\hline 3 & Timeliness of services (the average number of delays per month) & $1-5$ \\
\hline 4 & $\begin{array}{l}\text { Number of administrative services refusal delivery (monthly } \\
\text { average) }\end{array}$ & $1-5$ \\
\hline 5 & Number of complaints (monthly average) & $1-5$ \\
\hline 6 & $\begin{array}{l}\text { Number of certificates, honours, rewards, positive feedback from } \\
\text { Administrative Service Centre' visitors }\end{array}$ & $1-5$ \\
\hline \multicolumn{2}{|l|}{ Total Score (maximum) } & $\mathbf{3 0}$ \\
\hline
\end{tabular}

Administrative Service Centres, and observed staff work. The regulatory documents governing the Administrative Service Centre work have been investigated, including the list of public services, completeness of information on the web-site, knowledge and technological cards of administrative services. The information obtained from the processing and interpreting input data, reviews of the Administrative Service Centre infrastructure and communications with officials, were recorded and evaluated appropriately. The experts have prepared relevant reports outlining the positive trends and problematic issues and targeted recommendations for improving the Administrative Service Centres work and the united territorial community in every monitored city.

Table 3. Contest evaluation form sample "The best Administrative Service Centre' administrator"

\begin{tabular}{|l|l|l|}
\hline № & \multicolumn{1}{|c|}{ Participant } & \multicolumn{1}{c|}{ The impact of study results } \\
\hline 1 & $\begin{array}{l}\text { Administrative } \\
\text { Management }\end{array}$ & $\begin{array}{l}\text { Obtaining expert recommendations and specific proposals } \\
\text { for Administrative Service Centres development, } \\
\text { highlighting positive trends and issues, making critical } \\
\text { managerial decisions and developing Roadmap with } \\
\text { development prospects, introducing an annual analysis of } \\
\text { comments and suggestions on services quality }\end{array}$ \\
\hline 2 & $\begin{array}{l}\text { Administrative } \\
\text { Service Centre } \\
\text { employees }\end{array}$ & $\begin{array}{l}\text { Obtaining the expert results of staff activity evaluation, } \\
\text { identifying key indicators which is necessary to increase } \\
\text { the efficiency of their work, receiving moral and material } \\
\text { incentives as rewards for the best employees }\end{array}$ \\
\hline 3 & Experts & $\begin{array}{l}\text { Obtaining access to «field data», combining theoretical } \\
\text { approaches with essential information, getting more } \\
\text { opportunities to fully understand the Administrative } \\
\text { Service Centre activities in the Ternopil region, and a } \\
\text { possibility to conduct analytical calculations and test } \\
\text { some theoretical methods. }\end{array}$ \\
\hline 4 & $\begin{array}{l}\text { Local } \\
\text { governments } \\
\text { Administrative Service Centres efficiency in a particular } \\
\text { region, gaining more opportunities to learn the experience } \\
\text { of the best Centers in Ternopil region and develop } \\
\text { specific proposals at the regional level aimed at increasing } \\
\text { impact on the implementation of legislative changes in the } \\
\text { national context }\end{array}$ \\
\hline 5 & $\begin{array}{l}\text { Receiving proposals with changes from local } \\
\text { governments, increasing the efficiency of interaction } \\
\text { among administrative bodies to increase the level of } \\
\text { functionality of Administrative Service Centres in } \\
\text { Ternopil region }\end{array}$ \\
\hline authorities & $\begin{array}{l}\text { Increasing the integration of services, the prospects of } \\
\text { opening additional territorial divisions and jobs of } \\
\text { Administrative Service Centres, improving sites and } \\
\text { organizing information, increasing the Administrative } \\
\text { Service Centres area and improving infrastructure, } \\
\text { introducing the e-pay for services, improving conditions } \\
\text { for people with disabilities, increasing the number of } \\
\text { requests accepted by one administrator }\end{array}$ \\
\hline Service users
\end{tabular}


Table 4. Summary evaluation results of the Administrative Service Centres in 3 cities of regional (oblast) importance in Ternopil region

\begin{tabular}{|c|c|c|c|c|}
\hline № & Criteria & $\begin{array}{l}\text { Maximum } \\
\text { score }\end{array}$ & $\begin{array}{l}\text { Average score } \\
\text { (for three } \\
\text { cities of } \\
\text { regional } \\
\text { importance) }\end{array}$ & $\begin{array}{l}\% \\
\text { (Actual score / } \\
\text { Maximum score } \\
* 100 \% \text { ) }\end{array}$ \\
\hline 1 & $\begin{array}{l}\text { Compliance of the Administrative Service Centre' } \\
\text { premises with established standards (minimum } 100 \mathrm{~m}^{2} \text {, } \\
\text { maximum } 513 \mathrm{~m}^{2} \text { ) }\end{array}$ & 5 & 2,67 & 53,33 \\
\hline 2 & $\begin{array}{l}\text { The actual number of administrators in the } \\
\text { Administrative Service Centre (maximum - } 18 \text { people) }\end{array}$ & 5 & 4,00 & 80,00 \\
\hline 3 & $\begin{array}{l}\text { Number of administrative services provided per } \\
\text { administrator per year (minimum 700) }\end{array}$ & 5 & 4,00 & 80,00 \\
\hline 4 & $\begin{array}{l}\text { Availability of infrastructure for disabled people (ramp, } \\
\text { call button, toilet, etc.) }\end{array}$ & 5 & 1,33 & 26,67 \\
\hline 5 & $\begin{array}{l}\text { Technologically-advanced administrator's workplaces } \\
\text { (computer, photocopier, printer, etc.) }\end{array}$ & 5 & 5,00 & 100,00 \\
\hline 6 & $\begin{array}{l}\text { Number of administrative service types provided by the } \\
\text { Administrative Service Centre and regulated by relevant } \\
\text { legislation (maximum 260) }\end{array}$ & 5 & 4,00 & 80,00 \\
\hline 7 & $\begin{array}{l}\text { Free public access to bylaws, regulations, work } \\
\text { schedules, information cards for receiving administrative } \\
\text { services and information stands }\end{array}$ & 5 & 5,00 & 100,00 \\
\hline 8 & $\begin{array}{l}\text { Number of requests to the Administrative Service Centre } \\
\text { / administrative services provided (maximum } \\
16000 / 15000 \text { ) }\end{array}$ & 5 & 4,00 & 80,00 \\
\hline 9 & $\begin{array}{l}\text { The content of the Administrative Service Centre web- } \\
\text { site/webpage covering full information about its } \\
\text { activities }\end{array}$ & 5 & 3,00 & 60,00 \\
\hline 10 & $\begin{array}{l}\text { Provision of related services, in particular, making a } \\
\text { payment for these services (cash, non-cash, payment } \\
\text { terminal) }\end{array}$ & 5 & 2,33 & 46,67 \\
\hline 11 & $\begin{array}{l}\text { Feedback from the public, business entities and } \\
\text { representatives of the administrative service providers on } \\
\text { the work of the Administrative Service Centres } \\
\text { registered in the established order during the previous } \\
\text { calendar year before the date of the competition } \\
\text { (complaints and suggestion box, positive feedback) }\end{array}$ & 5 & 3,67 & 73,33 \\
\hline 12 & $\begin{array}{l}\text { The use of innovations in the Administrative Service } \\
\text { Centre ensuring practical work }\end{array}$ & 5 & 3,67 & 73,33 \\
\hline 13 & $\begin{array}{l}\text { Has the Administrative Service Centre received } \\
\text { assistance from local or international technical assistance } \\
\text { programs for the modernization or creation of the } \\
\text { Administrative Service Centre? If yes, in which ones? } \\
\text { (EU / UNDP, U-LEAD with Europe, GIZ, DOBRE, } \\
\text { Transparent Office) }\end{array}$ & 5 & 1,67 & 33,33 \\
\hline 14 & $\begin{array}{l}\text { Has the Administrative Service Centre previously } \\
\text { participated in competitions? If yes, in which ones and } \\
\text { what exact place did Centre win? }\end{array}$ & 5 & 1,67 & 33,33 \\
\hline \multicolumn{2}{|r|}{ Total score } & 70 & 46,00 & 65,71 \\
\hline
\end{tabular}

During July-August, 2019, the officials of mentioned evaluation results made it possible to identify and evaluate cities and the united territorial community have conducted self-assessment of the Administrative Service Centres activity using the same methodology as applied in MayJune 2019. The questionnaires filled out by officials were processed and analyzed by the experts following the information and documents provided. In this way, the objectivity of public services quality evaluation and Administrative Service Centres assessment was ensured. The purpose of self-assessment was to gain practical skills, better understand certain criteria, and apply them to improve the public services quality and Administrative Service Centres activity. During the questionnaire analysis, the evaluation results by the main criteria of each area were used. Provision of administrative services in mentioned cities and the united territorial communities has been analyzed. The recommendations for improving the public services quality and Administrative Service Centres activity have been given. A comparative analysis of each Administrative Service Centre's trends. The evaluation was carried out in general and in three types of territorial units: 1) cities of regional importance 2) towns of rayon importance and 3 ) the united territorial community. On the same principle, the evaluation results were presented.

The proposed evaluation methodology has significant practical significance, which is as follows:

1) for the first time a comprehensive study of the Administrative Service Centres was conducted in Ternopil region, which allowed to single out critical indicators of their development in 2018-2019, identify positive trends and issues, as well as give important recommendations for improving their efficiency;

2) the evaluation methodology allowed to combine the results of expert work and self-assessment of Administrative Service Centres in the Ternopil region. This allowed increasing the objectivity and complexity of the 
Table 5. Summary evaluation results of the Administrative Service Centres in the united territorial communities in Ternopil region

\begin{tabular}{|c|c|c|c|c|}
\hline № & Criteria & $\begin{array}{l}\text { Maximum } \\
\text { score }\end{array}$ & $\begin{array}{c}\text { Average score } \\
\text { (for three cities of } \\
\text { regional importance) }\end{array}$ & $\begin{array}{c}\% \\
\text { (Actual score / } \\
\text { Maximum } \\
\text { score } * 100 \%)\end{array}$ \\
\hline 1 & $\begin{array}{l}\text { Compliance of the Administrative Service Centre' premises } \\
\text { with established standards (minimum } 50 \mathrm{~m}^{2} \text {, maximum } 350 \mathrm{~m}^{2} \text { ) }\end{array}$ & 5 & 3,00 & 60,00 \\
\hline 2 & $\begin{array}{l}\text { The actual number of administrators in the Administrative } \\
\text { Service Centre (maximum - } 9 \text { people) }\end{array}$ & 5 & 3,00 & 60,00 \\
\hline 3 & $\begin{array}{l}\text { Number of administrative services provided per administrator } \\
\text { per year (minimum 400) }\end{array}$ & 5 & 3,00 & 60,00 \\
\hline 4 & $\begin{array}{l}\text { Availability of infrastructure for disabled people (ramp, call } \\
\text { button, toilet, etc.) }\end{array}$ & 5 & 4,00 & 80,00 \\
\hline 5 & $\begin{array}{l}\text { Technologically-advanced administrator's workplaces } \\
\text { (computer, photocopier, printer, etc.) }\end{array}$ & 5 & 5,00 & 100,00 \\
\hline 6 & $\begin{array}{l}\text { Number of administrative service types provided by the } \\
\text { Administrative Service Centre and regulated by relevant } \\
\text { legislation (maximum 260) }\end{array}$ & 5 & 3,00 & 60,00 \\
\hline 7 & $\begin{array}{l}\text { Free public access to bylaws, regulations, work schedules, } \\
\text { information cards for receiving administrative services and } \\
\text { information stands }\end{array}$ & 5 & 5,00 & 100,00 \\
\hline 8 & $\begin{array}{l}\text { Number of requests to the Administrative Service Centre / } \\
\text { administrative services provided (maximum 16000/15000) }\end{array}$ & 5 & 3,00 & 60,00 \\
\hline 9 & $\begin{array}{l}\text { The content of the Administrative Service Centre web- } \\
\text { site/webpage covering full information about its activities }\end{array}$ & 5 & 3,20 & 64,00 \\
\hline 10 & $\begin{array}{l}\text { Provision of related services, in particular, making a payment } \\
\text { for these services (cash, non-cash, payment terminal) }\end{array}$ & 5 & 3,00 & 60,00 \\
\hline 11 & $\begin{array}{l}\text { Feedback from the public, business entities and representatives } \\
\text { of the administrative service providers on the work of the } \\
\text { Administrative Service Centre, registered in the established } \\
\text { order during the previous calendar year before the date of the } \\
\text { competition (complaints and suggestion box, positive feedback) }\end{array}$ & 5 & 3,00 & 60,00 \\
\hline 12 & $\begin{array}{l}\text { The use of innovations in the Administrative Service Centre } \\
\text { ensuring sufficient work }\end{array}$ & 5 & 3,20 & 64,00 \\
\hline 13 & $\begin{array}{l}\text { Has the Administrative Service Centre received assistance from } \\
\text { local or international technical assistance programs for the } \\
\text { modernization or creation of the Administrative Service } \\
\text { Centre? If yes, in which ones? (EU / UNDP, U-LEAD with } \\
\text { Europe, GIZ, DOBRE, Transparent Office) }\end{array}$ & 5 & 4,00 & 80,00 \\
\hline 14 & $\begin{array}{l}\text { Has the Administrative Service Centre previously participated } \\
\text { in competitions? If yes, in which ones and what exact place did } \\
\text { Centre win? }\end{array}$ & 5 & 1,00 & 20,00 \\
\hline \multicolumn{2}{|r|}{ Total score } & 70 & 46,40 & 66,29 \\
\hline
\end{tabular}

study and identifying more criteria for a comprehensive assessment of Administrative Service Centre activity;

3) Experts' involvement made it possible to convert "field data" into quantitative analytical indicators. This allowed us to formulate Roadmaps and a list of recommendations for particular Center for Administrative Services. Thus, the management of the Centers received a real practical effect from working with experts;

4) the transformation of dissimilar data into a "score scale" allowed us to lead indicators with different measurement units and characteristics into a single basis. Thus, the experts provided an opportunity to compare these data and separate Administrative Service Centres with each other.

It was concretized the practical impact of the study on various participants in providing, regulating and receiving administrative services (table 3 ).

Thus, we can say that every participant of providing, managing, or receiving administrative services have got a real practical effect from the study. Thus, the survey significantly contributed to identifying real affairs and increasing the efficiency of providing services by the Administrative Service Centres in the Ternopil region.
During the assessment of the quality of administrative service delivery in 20 local governments in July-August 2019, both positive trends and problematic issues were identified in almost every one of them. The summary evaluation results of the Administrative Service Centres in three cities of regional (oblast) importance are presented in table 4.

In 2019, the overall average score of public services quality provided by the Administrative Service Centres in three oblast cities (Berezhany, Ternopil and Chortkiv) was 46 out of 70 possible. This is $15,71 \%$ above the average. It should be noted that the corresponding scores for each of these Administrative Service Centres varied significantly. It was observed that a score for two cities did not exceed 46 , then the substantially higher score (59) was recorded for one of them. The Administrative Service Centers received the highest scores due to the sufficiently high workload for one administrator, the availability of free access to up-to-date information, and participation in international technical assistance programs. The Administrative Service Centres' weaknesses were the insufficient content of web-site or webpage with relevant information on their work and the lack of information on procedures for providing related services, particularly, making cash or non-cash payments for these services. 
Table 6. Summary evaluation results of the Administrative Service Centres in twelve rayon state administrations of Ternopil region

\begin{tabular}{|c|c|c|c|c|}
\hline № & Criteria & $\begin{array}{l}\text { Maximum } \\
\text { score }\end{array}$ & $\begin{array}{l}\text { Average score } \\
\text { (for } 20 \text { rayon } \\
\text { state } \\
\text { administrations) }\end{array}$ & $\begin{array}{c}\% \\
\text { (Actual } \\
\text { score / } \\
\text { Maximum } \\
\text { score * } \\
100 \% \text { ) } \\
\end{array}$ \\
\hline 1 & $\begin{array}{l}\text { Compliance of the Administrative } \\
\text { Service Centre' premises with } \\
\text { established standards (minimum } 50 \mathrm{~m}^{2} \text {, } \\
\text { maximum } 102 \mathrm{~m}^{2} \text { ) }\end{array}$ & 5 & 2,25 & 45,00 \\
\hline 2 & $\begin{array}{l}\text { The actual number of administrators in } \\
\text { the Administrative Service Centre } \\
\text { (maximum of five people) }\end{array}$ & 5 & 3,50 & 70,00 \\
\hline 3 & $\begin{array}{l}\text { Number of administrative services } \\
\text { provided per administrator per year } \\
\text { (minimum 400) }\end{array}$ & 5 & 3,50 & 70,00 \\
\hline 4 & $\begin{array}{l}\text { Availability of infrastructure for } \\
\text { disabled people (ramp, call button, } \\
\text { toilet, etc.) }\end{array}$ & 5 & 3,58 & 71,67 \\
\hline 5 & $\begin{array}{l}\text { Technologically-advanced } \\
\text { administrator's workplaces (computer, } \\
\text { photocopier, printer, etc.) }\end{array}$ & 5 & 5,00 & 100,00 \\
\hline 6 & $\begin{array}{l}\text { Number of administrative service types } \\
\text { provided by the Administrative Service } \\
\text { Centre and regulated by relevant } \\
\text { legislation (maximum 260) }\end{array}$ & 5 & 2,42 & 48,33 \\
\hline 7 & $\begin{array}{l}\text { Free public access to bylaws, } \\
\text { regulations, work schedules, } \\
\text { information cards for receiving } \\
\text { administrative services and information } \\
\text { stands }\end{array}$ & 5 & 5,00 & 100,00 \\
\hline 8 & $\begin{array}{l}\text { Number of requests to the } \\
\text { Administrative Service Centre / } \\
\text { administrative services provided } \\
\text { (maximum } 16000 / 15000 \text { ) }\end{array}$ & 5 & 2,83 & 56,67 \\
\hline 9 & $\begin{array}{l}\text { The content of the Administrative } \\
\text { Service Centre web-site/webpage } \\
\text { covering full information about its } \\
\text { activities }\end{array}$ & 5 & 1,83 & 36,67 \\
\hline 10 & $\begin{array}{l}\text { Provision of related services, in } \\
\text { particular, making a payment for these } \\
\text { services (cash, non-cash, payment } \\
\text { terminal) }\end{array}$ & 5 & 2,50 & 50,00 \\
\hline 11 & $\begin{array}{l}\text { Feedback from the public, business } \\
\text { entities and representatives of the } \\
\text { administrative service providers on the } \\
\text { work of the Administrative Service } \\
\text { Centre, registered in the established } \\
\text { order during the previous calendar year } \\
\text { before the date of the competition } \\
\text { (complaints and suggestion box, } \\
\text { positive feedback) }\end{array}$ & 5 & 3,33 & 66,67 \\
\hline 12 & $\begin{array}{l}\text { The use of innovations in the } \\
\text { Administrative Service Centre } \\
\text { ensuring sufficient work }\end{array}$ & 5 & 1,17 & 23,33 \\
\hline 13 & $\begin{array}{l}\text { Has the Administrative Service Centre } \\
\text { received assistance from local or } \\
\text { international technical assistance } \\
\text { programs for the modernization or } \\
\text { creation of the Administrative Service } \\
\text { Centre? If yes, in which ones? (EU / } \\
\text { UNDP, U-LEAD with Europe, GIZ, } \\
\text { DOBRE, Transparent Office) }\end{array}$ & 5 & 1,42 & 28,33 \\
\hline 14 & $\begin{array}{l}\text { Has the Administrative Service Centre } \\
\text { previously participated in competitions? } \\
\text { If yes, in which ones and what exact } \\
\text { place did the Centre win? }\end{array}$ & 5 & 1,00 & 20,00 \\
\hline \multicolumn{2}{|c|}{ Total score } & 70 & 39,33 & 56,19 \\
\hline
\end{tabular}

Therefore, the study results suggest that the overall average score of quality of the public services provided by the Administrative Service Centres of five united territorial communities (in Shumsk, Pidvolochysk, Skalat, Velyki Hai and Velyki Dederkaly) in 2019 was 46,4 out of 70 possible.

This is $16,29 \%$ above the average. It should be noted that the corresponding scores for each of these Administrative Service Centres varied significantly. Thus, the lowest score (33) was only for the one united territorial community, while the average scores ranged from 42 to 52 for three united territorial communities. According to the evaluation results, only one of the Administrative Service Centre of the united territorial community scored 59 points, which is $34,3 \%$ higher than the average. These main differences in scores between the Administrative Service Centres of the united territorial communities are caused by the different period of its work (some of them are established relatively recently), the non-compliance of Administrative Service Centre' premises with established standards, the relatively small number of public services provided in the newly established administrative centres, the low innovation level and different population in every united territorial community. Major Administrative Service Centres' strengths in the united territorial communities include technologicallyadvanced administrator's workplaces, infrastructure for disabled people, and free access to up-to-date information.

The highest scores were given to the Adminis trative Service Centres due to the sufficiently high workload per administrator and free public access to relevant information. The Administrative Service Centres' weaknesses were the insufficient content of web-site or webpage with relevant information on their work and the lack of information on procedures for providing related services, particularly, making cash or non-cash payments for these services. Summary evaluation results of the Administrative Service Centres in twelve rayon state administrations of Ternopil region are given in table 6 .

Thus, according to the evaluation of Administrative Service Centres in twelve rayon state administrations, we concluded that the overall average score of public services quality in 2019 was 39,33 out of 70 possible. This is $6,19 \%$ above the Summary evaluation results of the Administrative Service average. This indicates that the quality of service Centres in the united territorial communities in Ternopil region are given in table 5 . average. This indicates that the quality of service
provided by the Administrative Service Centres at the level of rayon state administrations is much lower than 
Table 7. Summary contest results on "The best administrator" in the cities of oblast importance, the united territorial community and rayon state administrations in Ternopil region (oblast)

\begin{tabular}{|c|c|c|c|c|c|c|c|c|}
\hline № & Criteria & $\begin{array}{c}\text { Maximum } \\
\text { score }\end{array}$ & $\begin{array}{l}\text { Average } \\
\text { score } \\
\text { (for four } \\
\text { cities of } \\
\text { oblast } \\
\text { importance) }\end{array}$ & $\begin{array}{c}\% \\
\text { (actual } \\
\text { score / } \\
\text { maximum } \\
\text { score } * \\
100 \%)\end{array}$ & $\begin{array}{l}\text { Average score } \\
\text { (for five } \\
\text { united } \\
\text { territorial } \\
\text { communities) }\end{array}$ & $\begin{array}{c}\% \\
\text { (actual } \\
\text { score / } \\
\text { maximum } \\
\text { score* } \\
100 \%)\end{array}$ & $\begin{array}{l}\text { Average } \\
\text { score } \\
\text { (for } 15 \\
\text { rayon } \\
\text { state } \\
\text { administr } \\
\text { ations } \\
\end{array}$ & $\begin{array}{c}\% \\
\text { (actual score / } \\
\text { maximum } \\
\text { score } * 100 \% \text { ) }\end{array}$ \\
\hline 1 & $\begin{array}{l}\text { Administrator's } \\
\text { working period in the } \\
\text { Administrative } \\
\text { Service Centre on the } \\
\text { day of competition } \\
\text { announcement }\end{array}$ & 5 & 3,67 & 73,33 & 3,00 & 60,00 & 3,39 & 67,78 \\
\hline 2 & $\begin{array}{l}\text { Number of } \\
\text { administrative services } \\
\text { provided by given } \\
\text { administrator for } \\
\text { previous year prior to } \\
\text { the competition date }\end{array}$ & 5 & 2,89 & 57,78 & 3,00 & 60,00 & 2,33 & 46,67 \\
\hline 3 & $\begin{array}{l}\text { Timeliness of services } \\
\text { (average number of } \\
\text { delays per month) }\end{array}$ & 5 & 5,00 & 100,00 & 5,00 & 100,00 & 5,00 & 100,00 \\
\hline 4 & $\begin{array}{l}\text { Number of } \\
\text { administrative services } \\
\text { refusal delivery } \\
\text { (monthly average) }\end{array}$ & 5 & 4,44 & 88,89 & 4,60 & 92,00 & 4,00 & 80,00 \\
\hline 5 & $\begin{array}{l}\text { Number of complaints } \\
\text { (monthly average) }\end{array}$ & 5 & 5,00 & 100,00 & 5,00 & 100,00 & 5,00 & 100,00 \\
\hline 6 & $\begin{array}{l}\text { Number of } \\
\text { certificates, honors, } \\
\text { rewards, positive } \\
\text { feedback from } \\
\text { Administrative } \\
\text { Service Centre' } \\
\text { visitors }\end{array}$ & 5 & 1,89 & 37,78 & 3,40 & 68,00 & 2,33 & 46,67 \\
\hline \multicolumn{2}{|c|}{ Total score } & 30 & 22,89 & 76,30 & 24,00 & 80,00 & 22,06 & 73,52 \\
\hline
\end{tabular}

in united territorial communities or cities of oblast importance. The most problematic issues of rayon state administrations work were the lack of innovations in the Administrative Service Centres, the low participation in local and international technical assistance programs, and the small number of reviews from the service user and economic entities. In most case, the complaints and suggestions box was either empty or only contained a few mostly positive reviews. The Administrative Service Centres' strengths in the investigated rayon state administrations of Ternopil oblast were a flexible arrangement of administrator' workplaces and up-to-date information placement on the Administrative Service stands Centres.

The distribution of corresponding average scores among the Administrative Service Centres surveyed in rayon state administrations shows that ten received average scores were ranging between 35 and 41 . And only two Administrative Service Centres had slightly higher scores, respectively 44 and 49 points.

To identify and motivate the best Administrative Service Centre' employee, the Ternopil Regional State Administration has announced a contest for the best Administrative Service Centre' employee. Table 6 summarizes the total score (maximum and actual scores, and percentage of full score) received by the top 32 Administrative Service Centre' staff for the quality of administrative service delivery under the six main evaluation criteria (Table 7 ).
The best Administrative Service Centre' employees' evaluation results showed a high level of timeliness in public service delivery, no delays in services delivery, no complaints, and fewer administrative services refusals. Some administrative services refusals were caused by information exchange procedures and requests satisfying between the Administrative Service Centres and other organizations. This is because the Administrative Service Centres is only intermediate in this service chain. There is a different work period of Administrative Service Centres because some of them were established recently, the others have been working no more than three years.

It should be noted that there are some differences concerning the number of administrative services provided. This indicator depends on the settlement's size; several villages joined the united territorial community and number of people servicing by every Administrative Service Centre.

\section{CONCLUSION}

Therefore, summarizing the results of assessing the quality of administrative services provision in twenty local self-government bodies of Ternopil oblast in May-August 2019 , it is worth pointing out the revealed positive trends and some challenging moments of their work.

Some positive trends include the following:

- the overall average score of administrative services quality provided by the Administrative Service Centres of cities of oblast importance, the united territorial commu- 
Table 8. Practical aspects of improving the Administrative Service Centres efficiency due to compliance with the expert recommendations

\begin{tabular}{|c|c|c|c|c|}
\hline \multirow[b]{2}{*}{ № } & \multirow[b]{2}{*}{ Criteria } & \multicolumn{3}{|c|}{$\begin{array}{c}\text { Evaluation of positive changes after taking into } \\
\text { account the expert assessments and } \\
\text { recommendations }\end{array}$} \\
\hline & & $\begin{array}{c}\text { Administrative } \\
\text { Services Centres } \\
\text { of cities of } \\
\text { oblast } \\
\text { importance }\end{array}$ & $\begin{array}{l}\text { Administrative } \\
\text { Services } \\
\text { Centres of the } \\
\text { United } \\
\text { Territorial } \\
\text { Communities }\end{array}$ & $\begin{array}{c}\text { Administrative } \\
\text { Services } \\
\text { Centres of } \\
\text { district state } \\
\text { administrations }\end{array}$ \\
\hline 1 & $\begin{array}{l}\text { Compliance of the Administrative Service Centre' } \\
\text { premises with established standards }\end{array}$ & + & & + \\
\hline 2 & $\begin{array}{l}\text { The actual number of administrators in the } \\
\text { Administrative Service Centre }\end{array}$ & + & + & \\
\hline 3 & $\begin{array}{l}\text { Number of administrative services provided per } \\
\text { administrator per year }\end{array}$ & & + & + \\
\hline 4 & Availability of infrastructure for disabled people & + & & + \\
\hline 5 & $\begin{array}{l}\text { Technologically-advanced administrator's } \\
\text { workplaces }\end{array}$ & + & + & + \\
\hline 6 & $\begin{array}{l}\text { Number of administrative service types provided } \\
\text { by the Administrative Service Centre and } \\
\text { regulated by relevant legislation }\end{array}$ & + & + & + \\
\hline 7 & $\begin{array}{l}\text { Free public access to bylaws, regulations, work } \\
\text { schedules, information cards for receiving } \\
\text { administrative services and information stands }\end{array}$ & + & + & \\
\hline 8 & $\begin{array}{l}\text { Number of requests to the Administrative Service } \\
\text { Centre }\end{array}$ & & + & + \\
\hline 9 & $\begin{array}{l}\text { The content of the Administrative Service Centre } \\
\text { web-site }\end{array}$ & + & & + \\
\hline 10 & $\begin{array}{l}\text { Provision of related services, in particular, making } \\
\text { a payment for these services }\end{array}$ & + & & + \\
\hline 11 & $\begin{array}{l}\text { Feedback from the public, business entities and } \\
\text { representatives of the administrative service } \\
\text { providers on the work of the Administrative } \\
\text { Service Centre, registered in the established order } \\
\text { during the previous calendar year before the date } \\
\text { of the competition }\end{array}$ & + & + & + \\
\hline 12 & $\begin{array}{l}\text { The use of innovations in the Administrative } \\
\text { Service Centre ensuring practical work }\end{array}$ & + & + & + \\
\hline 13 & $\begin{array}{l}\text { Receiving of assistance from local or international } \\
\text { technical assistance programs for the } \\
\text { modernization or creation of the Administrative } \\
\text { Service Centre }\end{array}$ & + & & + \\
\hline 14 & Participating in competitions & + & + & \\
\hline
\end{tabular}

nities, and district state administrations is higher than the average. It means that most Administrative Service Centres operate efficiently and continuously improve their work;

- the Administrative Service Centres received the highest scores for high administrator' workload (number of administrative services provided by administrator), the availability of free access to up-to-date information, and participation in international technical assistance programs;

- the strengths of Administrative Service Centres in the rayon state administrations of Ternopil oblast include the technologically-advanced and flexible arrangement of administrator' workplaces and up-to-date information placement on the stands in the Administrative Service Centres;

- the evaluation results of the best Administrative Service Centre' employees showed a high level of timeliness in public service delivery, no delays in services delivery, no complaints, and fewer administrative services refusals.

Some difficult moments revealed during the evaluation include:
- the corresponding scores for each of these Administrative Service Centres significantly fluctuated. This means that it is too early to talk about a sufficiently adequate and sustainable development of administrative services;

- the weaknesses of the Administrative Service Centres were the insufficient content of web-site or webpage with relevant information on their work, as well as the lack of information on procedures for providing related services, in particular, making cash or non-cash payments for these services;

- there is the general trend that the quality of service provided by the Administrative Service Centres of district state administrations is much lower than in the united territorial communities or cities of oblast importance;

- the most problematic issues of rayon state administrations work were the lack of innovations in Administrative Service Centres, the low participation in local and international technical assistance programs, and the small number of reviews from the service user and economic entities.

The evaluation results will summarize and systematize all critical aspects of Administrative Service Centres work 
at the regional level, to develop recommendations and practical measures to improve their further development. The implementation of these practical measures has helped to increase the Administrative Service Centres efficiency in various aspects. This is evidenced by the article's online survey results in April-June 2020 (Table 8).

Thus, we can note that the expert evaluation results and the provided targeted proposals in 2019 became a guideline for improving services quality provided by the Administrative Service Centres in Ternopil region according to specific criteria.

We consider the prospects for further research to be the annual monitoring of the Administrative Service Centres work and their employees by the proposed methodology to use the evaluation criteria and indicators and analyze growth rates in Centres performance over particular periods.

\section{References:}

1. Alonso, P. and Lewis, G. (2001), "Public service motivation and job performance: Evidence from the federal sector", American Review of Public Administration, vol. 31, pp. 363-380. URL: https://doi.org/ 10.1177/02750740122064992

2. Audette-Chapdelaine, M. (2016), "Sensemaking and the political-administrative interface: the challenges of strategically steering and managing a local public service", International Review of Administrative Sciences, vol. 82 , pp. 454-471. URL: https:// doi.org/10.1177/0020852315594857

3. Battaglio, P. and French E. "Public Service Motivation, Public Management Reform, and Organizational Socialization: Testing the Effects of Employment-At-Will and Agency on PSM Among Municipal Employees", International Review of Administrative Sciences, vol. 45, pp.123-147. URL: https://doi.org/10.1177/0091026016644623

4. Brewer, G. Selden, S. and Facer, R. (2000), "Individual conceptions of public service motivation", Public Administration Review, vol. 60, pp. 254-264. URL: https://doi.org/10.1111/0033-3352.00085

5. Brygilevych, I. (2017), Diyalnist CzNAP ta ocinka yakosti nadannya administratyvnyx poslug [Center's for administrative services activities and quality assessment of administrative services], Kyiv, Ukraine, available at: https://decentralization.gov.ua/uploads/library/file / 15/Posibniik_CNAP.pdf (Accessed 10 April 2021).

6. Rusaw, C. (2007), "Changing Public Organizations: Four Approaches", International Journal of Public Administration, vol. 30, pp. 347-361. https://doi.org/ 10.1080/01900690601117853

7. Kazmierczak-Piwko, L. Dubicki, P. and Dybikowska, A. (2019), "Economic and social aspects of the merger of territorial self-government units - Polish experience", Multidisciplinary Aspects of Production Engineering MAPE. Vol. 2 (1), pp. 559-569, available at: https:// content.sciendo.com/view/journals/mape/2/1/articlep559.xml?language =en (Accessed 10 April 2021).

8. Klimushyn, P. and Spasibov, D. (2018), "The methodological framework for ensuring provision of administrative services quality", Theory and Practice of
Public Administration, vol. 1 (60), pp. 1-8, available at: http://www.kbuapa.kharkov.ua/e-book/tpdu/2018-1/ doc/1/06.pdf (Accessed 10 April 2021).

9. Novak, J. Purta, M. Marciniak, T. Ignatowicz, K. and Rozenbaum, K. (2018), "The rise of Digital Challengers: How digitization can become the next growth engine for Central and Eastern Europe", available at: https:// digitalchallengers.mckinsey.com/files/Rise_of_Digital_Challengers_Perspective_Poland.pdf (Accessed 10 April 2021).

10. Sydorenko, N. (2017), "Methodology for monitoring the work of the administrative service centers: analysis and further areas of improvement", available at: http://maup.com.ua/assets/files/expert/6/11.pdf (Accessed 10 April 2021).

11. Trutkowski, C. (2016), "An effective local government office", Developing personnel competence to build efficient local administration. Foundation in Support of Local Democracy. Warsaw, available at: https:// rm.coe.int/a-tna-case-study-poland-an-effective-localgovernment-office-developin / 168075fbac (Accessed 10 April 2021).

12. Tymoshhuk V. and Kurinnyj, O. (2015), Administratyvni poslugy: stan i perspektyvy reformuvannya [Administrative services: state and prospects of reform], Centr polityko-pravovyx reform, Kyiv, Ukraine, available at: https://cnap.in.ua/wpcontent/uploads/2017/03/ \% D0\% $90 \%$ D0\% 9F_\% D $1 \% 81 \%$ D $1 \% 82 \%$ D0$\%$ B $\%$ D0 \% BD \% D $1 \% 96 \%$ D0 \% BF \% D0\%B5\%D1\%80\%D1\%81\%D0\%BF\%D0\%B5\%D0\%BA\%D $1 \% 82 \%$ D0 \% B $\%$ D0 \% B2\%D0\%B8_2015.pdf (Accessed 10 April 2021).

Стаття надійшла до редакчї 09.04.2021 p.

\section{WwW. dy.nayka.com.ua}

Електронне фахове видання

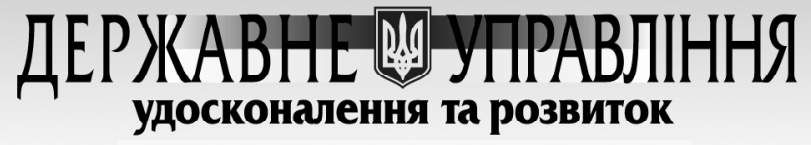

Виходить 12 разів на рік

включено до переліку наукових фахових видань України З Питань ДЕРЖАВНОГО УПРАВЛІННЯ

(Категорія «Б»)

Наказ Міністерства освіти і науки України від 28.12.2019 №1643

Спеціальність 281

e-mail:economy_2008@ukr.net

тел.: (044) 223-26-28, (044) 458-10-73 